\title{
Thrust-related river terrace development in relation to the 1999 Chi-Chi earthquake rupture, Western Foothills, central Taiwan
}

\author{
Wen-Shan Chen ${ }^{\mathrm{a}, *}$, Yue-Gau Chen ${ }^{\mathrm{a}}$, Ruey-Chyuan Shih ${ }^{\mathrm{b}}$, Tsung-Kwei Liu ${ }^{\mathrm{a}}$, Neng-Wei Huang ${ }^{\mathrm{a}}$, \\ Chin-Cheng Lin ${ }^{\mathrm{a}}$, Shih-Hua Sung ${ }^{\mathrm{a}}$, Kun-Jie Lee ${ }^{\mathrm{a}}$ \\ ${ }^{a}$ Department of Geosciences, National Taiwan University, 245 Choushan Road, Taipei 106, Taiwan, ROC \\ ${ }^{\mathrm{b}}$ Institute of Seismology, National Chung Cheng University, Chiayi, Taiwan, ROC
}

Received 30 January 2001; revised 23 May 2002; accepted 25 June 2002

\begin{abstract}
The 21 September 1999 earthquake $\left(M_{W} 7.6\right)$ produced a surface rupture that extended for $100-\mathrm{km}$ in a general north-south direction in front of the Western Foothills, central Taiwan. The study area, located in a segment of the fold-thrust belt of central Taiwan, provides an important natural laboratory to study the relationship between active thrust deformation and fluvial terrace development. We recognize, from west to east, three subparallel thrusts, the Sanyi, Houli, and Shihkang faults in the northern part of the earthquake disaster area. The 1999 earthquake rupture occurred only along the Shihkang fault, whereas the other two faults were inactive. Along the Tachia River in the hanging wall of the Shihkang fault, eight well-developed terrace levels are observed, and can be subdivided into lateritic (Lt5-Lt1) and non-lateritic terraces (Ft3-Ft1). Five levels of lateritic terrace (Lt5-Lt1) are located in the hanging wall of the Houli fault, and a lateritic terrace (Lt5) is present in the hanging wall of the Sanyi fault. Stratigraphic and elevation correlations between these well-developed fluvial terraces in relationship to nearby geologic structures show that the Sanyi fault is the oldest structure. Lateritic terraces of at least 10,000 yr BP, for example, overlie the Sanyi fault, but correlative terraces associated with the Houli fault are offset. These types of terrace correlations allow us to define the progressive development of the thrust system within the Western Foothills.
\end{abstract}

(C) 2002 Published by Elsevier Science Ltd.

Keywords: Fold-thrust belt; Chi-Chi earthquake; Surface rupture

\section{Introduction}

The Western Foothills are a west-verging fold-thrust belt related to recent arc-continental collision of the Asian continental plate with the Philippine Sea plate (Suppe, 1981; Angelier et al., 1986). The 21 September 1999 earthquake was located in the Western Foothills of central Taiwan. The focal mechanism of the mainshock indicated that the source rupture occurred at a focal depth of $10 \mathrm{~km}$ on a low-angle reverse fault dipping $30^{\circ} \mathrm{SE}$ (Chang et al., 2000; Fig. 1(a), A-A' profile). The surface rupture was along the active mountain-front, which lies within an intermontane zone between the Western Foothills and the Taichung piggyback basin (Fig. 1(a)).

The Western Foothills are part of an active fold-andthrust belt. The most conspicuous tectonic features in this area are north-trending thrust faults (Suppe, 1981, 1986).

\footnotetext{
* Corresponding author. Tel.: + 886-2-2369-2594; fax: + 886-2-23636095.

E-mail address: wenshan@ms.cc.ntu.edu.tw (W.-S. Chen).
}

Recent uplift of these thrust sheets results in river incision and development of complex fluvial terraces. Several lateritic and non-lateritic terraces, for example, are preserved along the Taan and Tachia Rivers (Fig. 1). In this area, complex reverse faults, such as the Sanyi, Houli, and Shihkang faults have uplifted and rotated the fluvial terraces (Fig. 1(a)). In addition, several minor active faults and folds are also present in this area (Chen et al., 2000a). Analysis of nearby fluvial systems provides a proxy for thrust deformation because localized long-term uplift produces anomalous changes in river systems. The purpose of this paper is to discuss how fluvial terraces can be used to determine fault activity and to show the tectonic implications of such findings.

\section{Geological setting and earthquake rupture}

The subduction of the Eurasian continent beneath the Philippine Sea plate is represented by the westernmost 


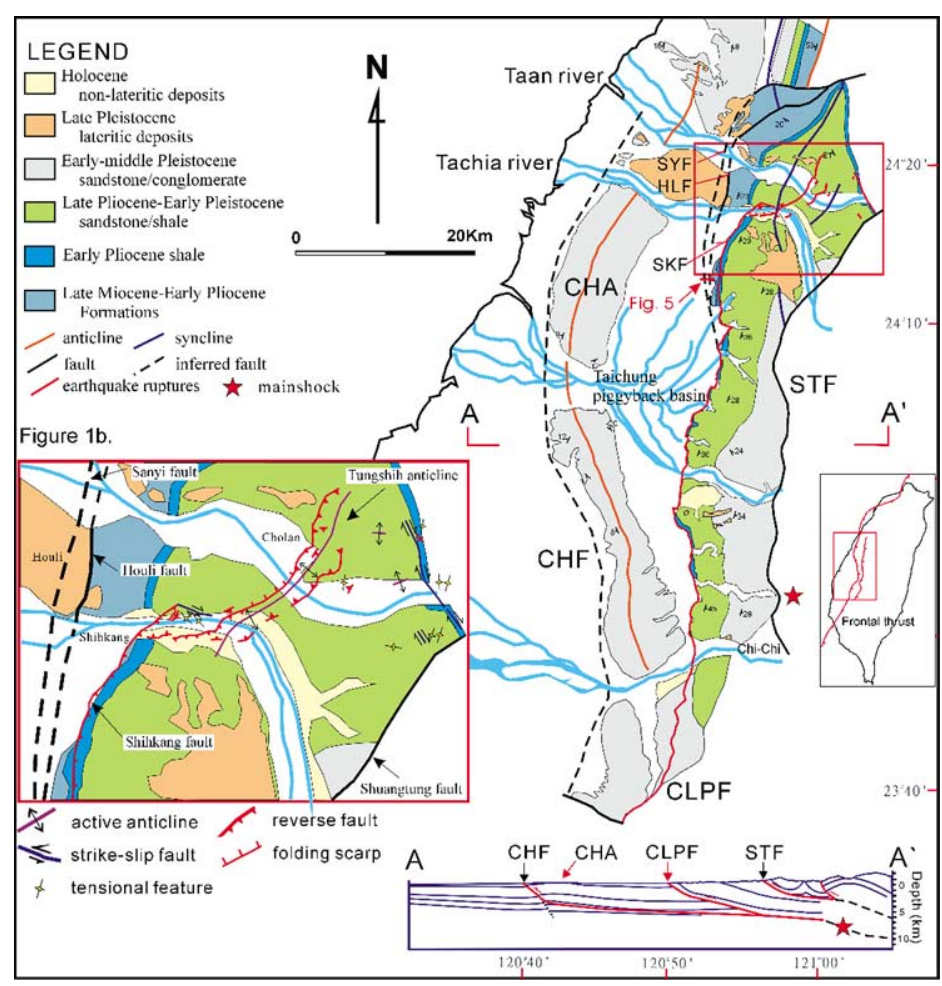

Fig. 1. (a) Geologic map of west-central Taiwan showing Chi-Chi earthquake surface ruptures. The Western Foothills in the central Taiwan contain eastdipping reverse faults, such as the Shuangtung, Chelungpu, and Changhua faults. The foothills are bounded by the Chelungpu fault. The Taichung basin, containing late Quaternary alluvium, is in the footwall of the Chelungpu fault. A published seismic profile of central Taiwan is re-projected onto the crosssection A-A' (Chiu, 1971). CHF, Changhua fault; CLPF, Chelungpu fault; STF, Shuangtung fault; SYF, Sanyi fault; HLF, Houli fault; SKF, Shihkang fault; CHA, Changhua anticline. (b) Earthquake ruptures and active folding in the Shihkang-Cholan area.

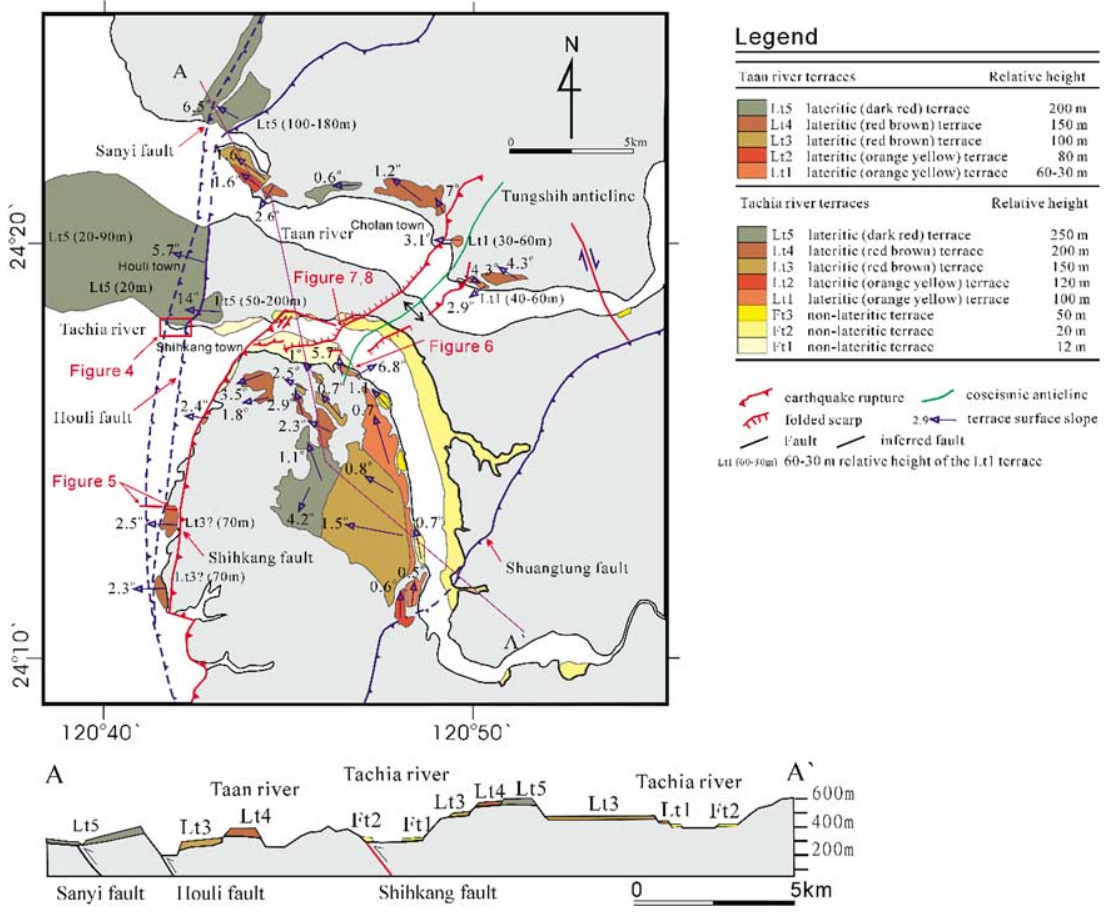

Fig. 2. Correlation of terraces using soil characteristics and relative height. Eight levels of river terrace are found along the Taan and Tachia Rivers. Crosssection $\mathrm{A}-\mathrm{A}^{\prime}$ shows the river terraces across the Sanyi, Houli, and Shihkang faults. Locations of other figures also shown. 
thrust of the Changhua fault in the Western Foothills (Angelier et al., 1986). The Western Foothills consist of a series of subparallel thrust faults and related folds, which form a west-verging fold-thrust belt. Fault-bend and faultpropagation fold structures are also common in the Western Foothills (Suppe, 1981). The thrust system in northern Taiwan is now inactive with normal-faults commonly reactivating former reverse faults (Teng, 1996). The Western Foothills in central Taiwan, however, have been a zone of active folding and thrusting throughout the late Quaternary. East-dipping reverse faults, such as the Shuangtung, Sanyi-Chelungpu, and Changhua faults characterize this area (Fig. 1; Chen et al., 2000a). In this area, the foothills are bounded by the Sanyi-Chelungpu fault, which is thrusting Pliocene-Pleistocene strata over modern sediments of the Taichung piggyback basin. The Sanyi-Chelungpu fault is one of the three major reverse faults in central Taiwan, but its neotectonic features have not been studied in detail (Meng, 1963; Chang, 1971).

The northern Chi-Chi earthquake disaster area, where it crosses the Taan and Tachia Rivers in central Taiwan, contains a number of the Quaternary geomorphologic features offset by faults and folds. Field mapping shows three subparallel thrusts, the Sanyi, Houli and Shihkang faults (Chen et al., 2000a; Fig. 1(a)). Based on the seismic reflection profile (Hung and Wiltschko, 1993; Hung and Suppe, 2000), these faults are east-dipping reverse faults, merging at depth with the Chelungpu fault. The Sanyi fault separates Miocene-Pleistocene strata in the hanging wall from the modern piggyback basin. The Houli fault is located within a Late Miocene shale, and is interpreted as a beddingslip fault. The Shihkang fault is located in a Pliocene shale and produced vertical surface ruptures of 3-10 m during the Chi-Chi earthquake. In a 'typical' fold-and-thrust belt, thrust faults commonly propagate basinward (Boyer and Elliott, 1982). Fortunately, in central Taiwan, there are a number of well developed fluvial terraces along the Taan and Tachia Rivers that allow precise correlation across the main thrust faults which allow us to test the direction of fault propagation in central Taiwan.

\section{Geomorphic features of terraces}

Fluvial systems are commonly sensitive to both faulting and regional surface deformation (Amorosi et al., 1996). Along the Tachia, Taan, Wushi and Choushui Rivers in central Taiwan, for example, complex river terraces are developed across the Chi-Chi earthquake rupture. Here, most terrace deposits consist of thick gravel sequences (10$40 \mathrm{~m}$ thick) that overlie Plio-Pleistocene strata with an erosional basal unconformity. Geomorphologic analysis using aerial photographs and 1:5000-scale topographic maps show a large number of different elevations for these river terraces along the Taan and Tachia Rivers. Lateritic soils are generally better developed on upper terraces relative to the lower terraces (Fig. 2).

Along the Tachia River, eight levels of river terraces, designated from the highest ( Lt5), to the lowest (Ft1), have been recognized. The Taan and Tachia Rivers cross several late Quaternary structures, the Sanyi, Houli, Shihkang faults and the Tungshih anticline (Fig. 3). Correlation of the eight terrace levels is based on soil characteristics and relative heights. In the syntectonic Plio-Pleistocene Taichung basin, we only found the Lt5 lateritic terrace which is as low as $20 \mathrm{~m}$ in relative height in this area (Fig. 2). In the foothills, lateritic terraces, however, are extensively developed at high elevation on the hanging wall of the Houli and Shihkang faults. At present, we do not have any dates from terrace surfaces. Terrace correlation, therefore, is based on lateritic characteristics. Lateritization in Lt5 extends to a depth of about 6-10 m-thick, and the dark red laterite consists of weathered quartizite boulders. The Lt5 terrace is often folded or tilted. The surface, therefore, makes a useful correlation marker for understanding the deformation. In contrast, soils developed in Lt4-Lt3 terraces are characterized by a $2-5 \mathrm{~m}$-thick red brown laterite layer with unweathered boulders (Fig. 2). The orange soils of Lt2Lt1 are only 2-3 m-thick. Although no quantitative evidence for the age of the Lt5-Lt1 surfaces are available, the lateritic terraces in the Western Foothills are at least older than 10,000 yr BP based on C14 dating (Liu, 1990; Chen and Liu, 1991). Soils of Ft3-Ft1 alluvial deposits are very thin and poorly developed. In this study, we collected some pottery flakes from Ft2 deposits obtaining $1300 \mathrm{yr}$ BP based on thermoluminescence dating. We estimate, therefore, that most non-lateritic terraces in the study area formed during the Holocene.

Using the relative heights and lithologic characteristics of terrace deposits, we can correlate terraces across major faults. Five levels of the lateritic terraces are found along the Taan River, which are situated between the Houli and Shihkang faults on the hanging wall of the Houli fault (Figs. 2 and 3). They are best developed on the northern bank of the Taan River. They have relative heights of 200, 150, 100, 80 and $50 \mathrm{~m}$ from the modern Taan River
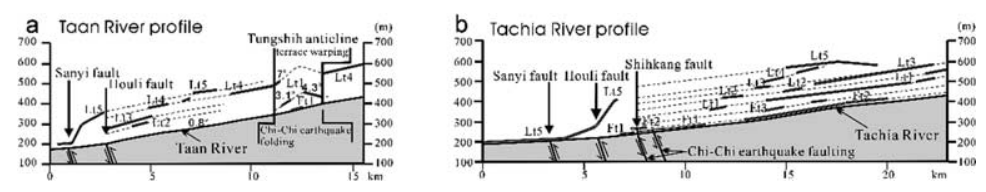

Fig. 3. (a) Longitudinal profile along the Taan River across the Sanyi fault, Houli fault and Tungshih anticline showing the altitudes of terraces. (b) Longitudinal profile along the Tachia River across the Sanyi, Houli, and Shihkang faults showing the altitudes of terraces. 


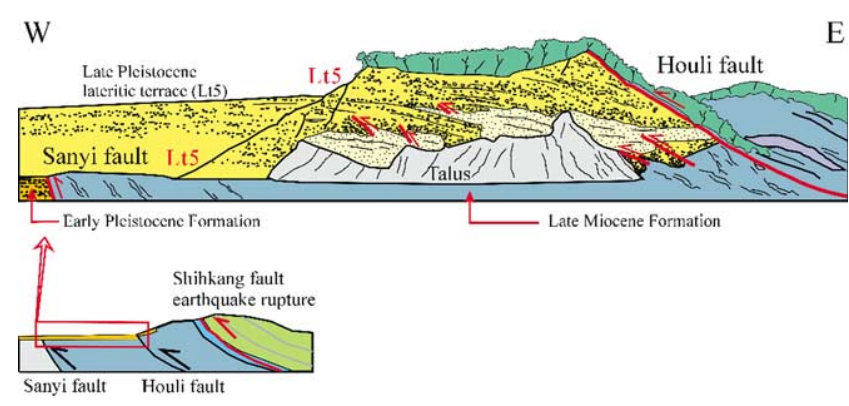

Fig. 4. East-west cross-section of the Sanyi fault. Note that the Sanyi fault is unconformably overlain by lateritic terrace Lt5. To the east, late Miocene strata are thrust over a lateritic terrace along the Houli fault.

streambed, corresponding to Lt5, Lt4, Lt3, Lt2 and Lt1 terraces, respectively (Fig. 2). It is noteworthy that nonlateritic terraces are rare; only one Ft1 terrace occurs on the crest of the Tungshih anticline (Fig. 3).

On the hanging wall of the Shihkang fault along the Tachia River, eight levels of river terraces are well developed. They can be classified as Lt5, Lt4, Lt3, Lt2, and $\mathrm{Lt} 1$ lateritic terraces, and $\mathrm{Ft} 3, \mathrm{Ft} 2$, and $\mathrm{Ft} 1$ non-lateritic terraces with relative heights of 250, 200, 150, 120, 100, 50, 20 , and $12 \mathrm{~m}$, respectively (Fig. 2; $\mathrm{A}-\mathrm{A}^{\prime}$ profile). These terraces are exposed in the southern bank of the Tachia River. Non-lateritic terraces were only documented along the Tachia River in the hanging wall of the Shihkang fault.

\section{Terrace correlation in relation to faults and folds}

Terraces were distinguished and correlated on the basis of their position above the nearby streambed and numbered from the youngest to the oldest. In addition, the degree of reddening of the surface soil was also used to help differentiate the various terraces (Figs. 2 and 3). As for Lt5 terraces, a thick-bedded dark red laterite usually defines the uppermost surface, providing a useful marker for correlation along and across the Taan and Tachia Rivers.

\subsection{Across the Sanyi fault}

The Sanyi fault is a major mountain-bounding thrust occurring along the eastern margin of the Taichung piggyback basin. This fault is unconformably overlain by an almost intact Lt5 lateritic-terrace (Fig. 4), having

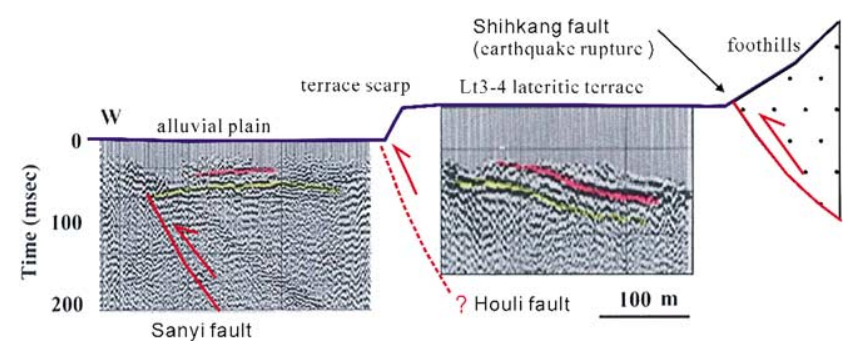

Fig. 5. Shallow seismic reflection along west-east-trending profiles from alluvial plain to the foothills across the Sanyi, Houli, and Shihkang faults.

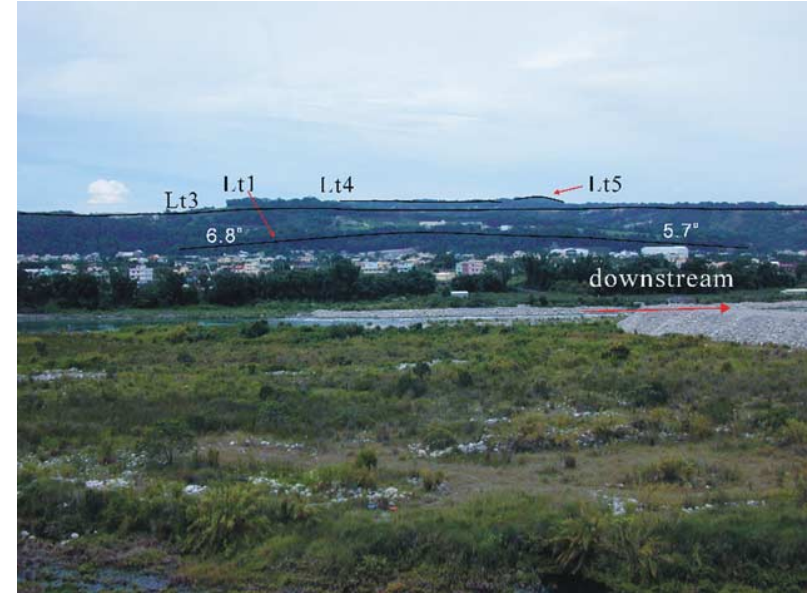

Fig. 6. Lt1 terrace along the southern Tachia riverbank defines an antiform surface which dips $6.8^{\circ}$ upstream along the eastern flank and dips $5.7^{\circ}$ downstream along the western flank.

a relative height of 20-m above the Tachia River streambed. High-resolution seismic reflection profiles indicate that the Sanyi fault in the Taichung basin is capped with undeformed sediments, implying that the fault has been inactive since the late Pleistocene (Fig. 5; Shih et al., 2000).

\subsection{Across the Houli fault}

East of the town of Houli, the Houli fault runs parallel to the Sanyi fault (Fig. 2). Exposures on the northern bank of the Tachia River are well exposed and almost continuous at river level. On the northern bank of the Tachia River, the Lt5 terrace consists of flatlying fluvial gravels that unconformably overlie Miocene strata. The Lt5 terrace is also transected by the Houli thrust. Several minor reverse-fault features extend a few meters into the terrace deposits in the footwall of the Houli fault suggesting significantly distributed shear (Fig. 4). The thrust fault has also tilted the terrace $14^{\circ}$ westward on the hanging wall, with the relative height of the deformed terrace surface between 20 and $200 \mathrm{~m}$ (Figs. 2 and 3 ). The highest terrace surface has a vertically offset of $200 \mathrm{~m}$ near the Houli fault. In addition, the Lt5 terrace on the northern bank of the Taan River shows a similar relationship and has a relative height of $200 \mathrm{~m}$ in the hanging wall. On both sides of the Houli fault, the height of the Lt5 surface obviously differs by $200 \mathrm{~m}$. This difference is consistent with our observation that the deformed terrace surfaces near the Houli fault are vertically offset by $200 \mathrm{~m}$. The Sanyi fault here does not appear to have had significant vertical displacement during deposition of the lateritic terraces.

The Houli fault covered by late Quaternary gravels in the Taichung basin, cannot be traced southward across the Tachia River. South of the Tachia River, the western margin of the foothills is marked by an abrupt mountain-front of Pliocene strata produced by reverse faulting. All rivers cut through the fault, and the mountain-front has been deposited as alluvial fans along the piedmont of the Western Foothills. 
The Houli fault cuts through and vertically offsets the piedmont alluvium. Many alluvial and fluvial terraces, therefore, are well developed on the uplifted side adjacent to the western margin of the foothills. Successive stream deposits in the uplifted hanging wall, for example, have formed several terraces along the Taan and Tachia Rivers. Many alluvial fans occur along the western margin of the foothills where these fans cross the mountain-front fault (i.e. the Chelungpu fault). Successive stream entrenchment in the uplifted hanging wall has formed numerous terraces; these terraces are undeveloped in the footwall (i.e. the Taichung basin). Segments of the Sanyi and Houli faults are buried beneath Holocene alluvial deposits under the Taichung basin. Mapping by seismic reflection in the Taichung basin near the Houli fault, documents well developed lateritic terrace scarps (Fig. 6). Geomorphologic evidence indicates that tectonic uplift may have produced at least part of this topographic high along these faults. For these reasons, we suggest that the Sanyi and Houli faults have been inactive since the Holocene. The Chi-Chi earthquake did not rupture these faults.

\subsection{Across the Shihkang fault}

The Shihkang fault, a range-bounding reverse fault, has a sinuous trace along the mountain-front (Fig. 2). Geomorphic features can also be used as a guide to delineate active faulting at the boundary between the Taichung basin and piedmont. On the hanging wall of this fault, there are five lateritic terraces and three non-lateritic terraces (Fig. 3). The multi-level terraces have a relatively asymmetrical distribution, progressively shifting eastward along the western bank of the Tachia River (Ku, 1963). Various orders of terraces can be seen as remnants on the western riverside. Asymmetry of the terrace distribution may be cited as evidence for ground tilting resulting in stream migration (Cox, 1994). The river response to a growing structure is dependent upon the rate of fluvial erosion, which is a function of stream power, riverbed erosion, and rate of uplift. If the rates of tectonic uplift are higher than the erosion rates, rivers encountering a growing fault will often be deviated (Gupta, 1997). Therefore, the Tachia River deviation is interpreted as a response to progressive uplifting of the foothills above the thrust faults.

The relative heights of Lt5, Lt4, Lt3, Lt2, and Lt1 terraces on both sides of the Shihkang fault appear to be offset by approximately $50 \mathrm{~m}$ (Fig. 2). This difference is equal to the relative height of the $\mathrm{Ft} 3$ terrace in the hanging wall. We propose that Lt5-Lt1 terraces formed before development of the Shihkang fault. After formation of the Shihkang fault, the hanging wall was progressively uplifted. We conclude that Ft3-Ft1 terraces are related to displacement on the Shihkang fault, whereas the Lt1 terrace was developed prior to faulting. In other words, displacement on the Houli fault ended prior to the formation of the Ft3 terrace. Furthermore, the lowest Ft1 terrace, which covers the Shihkang fault was cut and uplifted 3-m by the Chi-Chi earthquake rupture. Sometime prior to the Chi-Chi earthquake, displacement on the Shihkang fault cut the Ft1 terrace and formed a $12-20 \mathrm{~m}$ tilted terrace. In the Shihkang area, the earthquake rupture is primarily along the Ft1 terrace scarp and is generally interpreted as a product of coseismic uplift of the fluvial terrace. Based on the above characteristics, the Shihkang fault is interpreted as an active Holocene participant in fold-thrust belt deformation.

Based on the terrace data, a relationship between the bearing and position of the terraces and displacement on the Sanyi, Houli and Shihkang faults can be shown. The ChiChi earthquake resulted in 3-10 m of vertical displacement in the hanging wall of the Shihkang fault. This coseismic uplift formed a new terrace. We infer that repeated ancient earthquakes largely controlled by active faulting on the Sanyi, Houli, and Shihkang faults may have similarly produced the older terraces. The relationship between the terraces suggests out-of-sequence thrusting since the late Quaternary, with the Sanyi fault being the oldest, and the Shihkang fault the youngest.

\subsection{Across the Tungshih anticline}

The Cholan area is characterized by broad surface folding and faulting. The deformed region is bounded by several northwest-trending right-lateral strike-slip faults and contains northeast-trending tensile fractures from the ChiChi earthquake. A coseismic anticline formed due to deformation during the Chi-Chi earthquake. This structure is located at the pre-existing Tungshih anticline. We interpreted this anticline as a wrench-related compressional fold formed with a highly faulted core (Chen et al., 2000b). The anticlinal fold, about $1-\mathrm{km}$ wide, contains a conspicuous back thrust on its eastern limb and a broadly folded scarp on its western limb (Fig. 1(b)). The coseismic anticline crosses the Taan and Tachia Rivers so that the fluvial deposits have been tectonically tilted. The geomorphic features of terrace displacement define a steeper terrace-surface gradient near the fault and the core of the fold (Figs. 2 and 3(a) and (b)). The Taan riverbed was also folded and dips $2^{\circ}$ on both limbs which differs from the river gradient that ranged from 0.6 to $0.8^{\circ}$ before the earthquake. Several terraces along the Taan River are situated on both limbs of the Tungshih anticline and appear to have formed on a higher-angle terrace surface than the modern river gradient. On the eastern limb near the axis of the Tungshih anticline, the Lt1 terrace surface dips $4.3^{\circ}$ upstream (Figs. 2 and 3(a)). On the western limb, the Lt 4 and Lt 1 terraces dip 7 and $3.1^{\circ}$ downstream, respectively (Fig. 3(a)). Note that displacements are asymmetrical across the anticline axis and the younger terraces display a lesser gradient compared to the older terraces (Fig. 3(a)). On the Tachia River, the Lt1 terrace defines an antiformal surface that dips $6.8^{\circ} \mathrm{E}$ upstream and dips $5.7^{\circ} \mathrm{W}$ downstream (Figs. 3(b) and 6). 


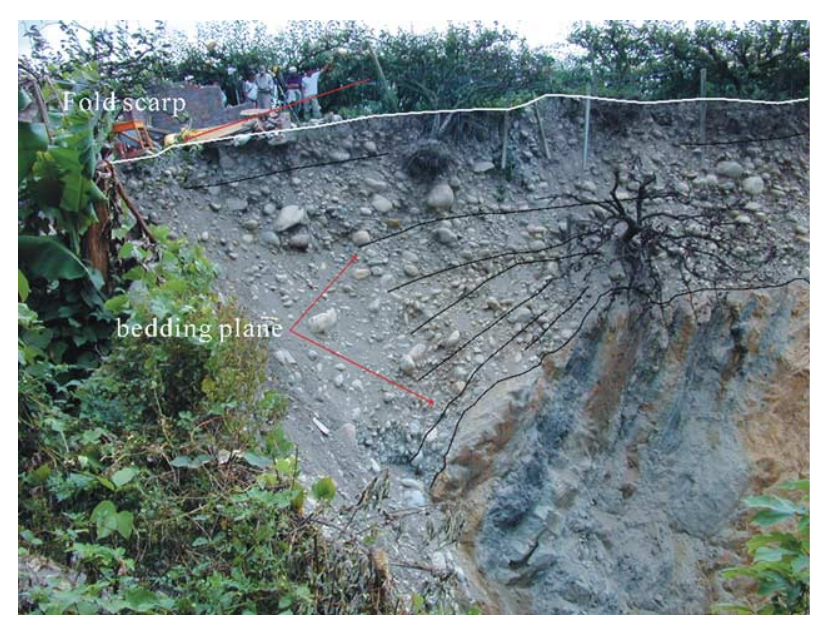

Fig. 7. Topographic expression of the pear field exhibited a folded scarp produced by the earthquake. Note that the gravel bed of terrace deposits on the fold scarp forms a wedge shape and the upper bed displays less inclination compared to the lower bed which dips $60^{\circ}$. Obviously, the gravel bed has progressively tilted over time. This site is $50 \mathrm{~m}$ apart from Fig. 8 .

The eastern limb of the terrace surface is tilted gently to the northeast, opposite to the modern riverbed, which slopes to the west. The structure is locally a convex-upward vertical uplift, which coincides with the anticlinal folding features associated with the 1999 Chi-Chi earthquake.

In addition, the Tungshih anticline contains evidence for active deformation during development of the Ft 2 terrace. A section of Ft 2 terrace deposits along the Tachia River indicate continued tilting on the western limb of a growing anticline (Fig. 2). For example, the oldest gravel bed in these terrace deposits dips at ca. $60^{\circ}$ and unconformably overlies folded Pleistocene strata (Fig. 7). The oldest gravel bed is overlain by a wedge-shaped gravel bed, which is interpreted as scarp deposits. The youngest gravel, located at the top of the terrace, dips $10^{\circ}$ on the western limb of the Tungshih anticline (the Chi-Chi earthquake-related fold; Figs. 7 and 8). Therefore, most Lt4, Lt1 and Ft2 terraces on both sides

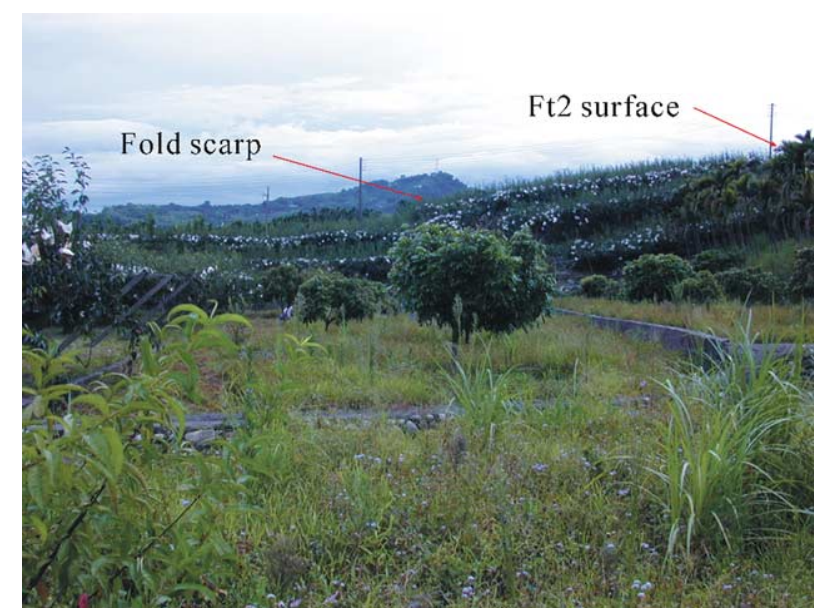

Fig. 8. The Chi-Chi earthquake formed a coseismic folded scarp along the western limb of the Tungshih anticline, ca. 5-m high.

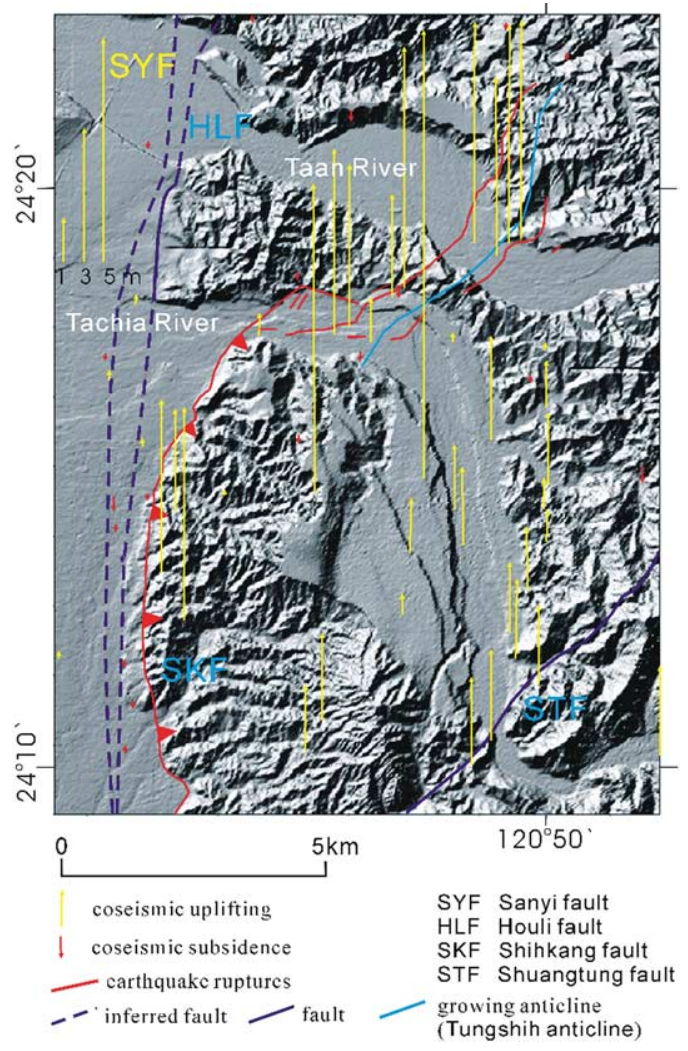

Fig. 9. The deformation recorded from GPS observations show coseismic uplift of 3-10 m on the hanging wall and subsidence of several decimeters in the footwall of the Shihkang fault, relative to the stable site in Kingmen Island, west of the Taiwan Strait (LSB, 1999; CGS, 1999).

of the anticline record fold-induced tilting. We conclude that the Tungshih anticline has been an active fold since the late Pleistocene.

\section{Summary}

GPS measurements after an earthquake can provide valuable geodetic data for understanding crustal deformation over larger surrounding areas. The deformation recorded from GPS observations after the 21 September 1999 earthquake show coseismic uplift changes of 3$10 \mathrm{~m}$ on the hanging wall of the Shihkang fault and subsidence of several decimeters on the footwall (Fig. 9). Detailed GPS measurements and field investigation provide evidence of major surface faulting along the Shihkang fault. The footwall of the Shihkang fault along the Sanyi and Houli faults, however, contains no visible coseismic surface deformation, but several decimeters of subsidence were recorded. The Taichung piggyback basin, loaded by the Western Foothills westward overthrusting along the Shihkang fault, is a long-term product of this subsidence. Coseismic uplift along the Shihkang fault was distributed broadly in a zone 5-20 km wide occupied by several active thrust fronts of the Western Foothills. As the thrust sheet is translated up a ramp structure it 


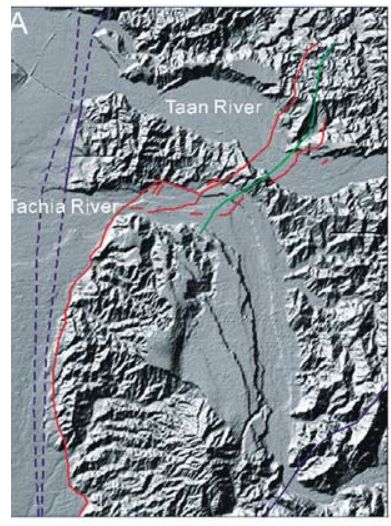

$5 \mathrm{~km}$

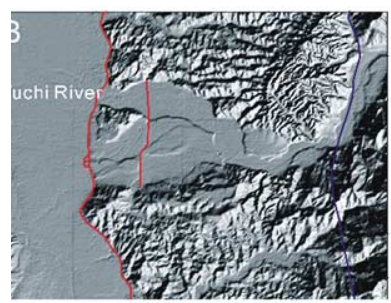

$5 \mathrm{~km}$
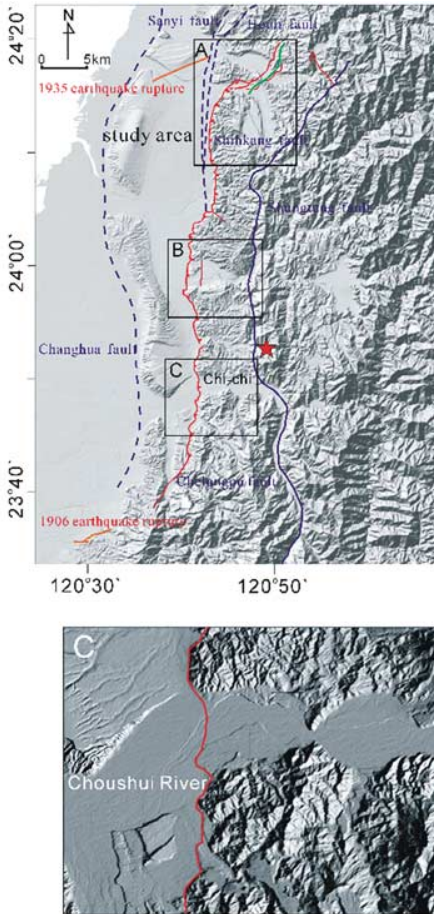

$5 \mathrm{~km}$ r mainshock located by star $>$ carthquake rupture - historical earthquake rupt fault ... inferred fault $/$ anticline

Fig. 10. DEM map of the 1999 ruptures and river terraces. The 1999 ruptures across the Taan, Tachia, Wushi, and Choushui Rivers displace alluvial deposits. Several Holocene river terraces were shown on the hanging wall, which appear to reflect in rapidly tectonic activity. (a) Eight different elevations of raised terraces are located on the hanging wall of the 1999 rupture, and elevation difference of the lateritic terraces cross the rupture. (b) The 1999 rupture extends along the pre-existing fault scarp across the Wushi River, which displays four levels of non-lateritic terraces and two levels of lateritic terraces on the hanging wall. (C) The 1999 rupture extends along the scarp of four levels of non-lateritic terraces.

produces near-surface uplift (Jackson and Bilham, 1994; Chen et al., 2001). Such a ramp is interpreted to be responsible for the recent uplift of the Western Foothills and is consistent with seismic reflection profiles. All the mountain-fronts are bounded by active faults or folds, suggesting that the highest tectonic activity is usually associated with a higher uplift rate. Therefore, we interpret the variable elevations of river terraces on the leading edge of the Shihkang-Chelungpu fault along the Taan, Tachia, Wushi and Choushui Rivers (Fig. 10) as being related to rapid uplift above the ramp. GPS measurements along the Tungshih anticline record large amounts of vertical displacements after the earthquake, ranging from 1 to 5.5-m high (LSB, 1999; Lee et al., 2000). Our geomorphologic data combined with the GPS measurements suggest a correlation between earthquake activity and development of Quaternary geomorphic features.

The Chi-Chi earthquake produced a surface rupture on the Shihkang fault and a coseismic Tungshih anticline.
Results of terrace correlation show that distribution of the terraces provides a detailed record of faulting and folding since the late Pleistocene. Geomorphologic analyses of the northern earthquake area along the Taan and Tachia Rivers display significant variation in elevation of correlative river terraces between various faults. Using the above observations and measurements, we infer that the elevation variation of terraces is a product of tectonic uplift above a ramp structure in the fold-thrust belt of the frontal Western Foothills. Our terrace measurements also suggest out-ofsequence thrusting for this part of the thrust belt in central Taiwan.

\section{References}

Amorosi, A., Farina, M., Severi, P., Preti, D., Caporale, L., Dio, G.Di., 1996. Genetically related alluvial deposits across active fault zones: an example of alluvial fan-terrace correlation from the upper Quaternary of the southern Po Basin, Italy. Sediment. Geol. 102, 275-295.

Angelier, J., Barrier, E., Chu, H.T., 1986. Plate collision and paleostress trajectories in a fold-thrust belt: the foothills of Taiwan. Tectonophysics $125,161-178$.

Boyer, S.E., Elliott, D., 1982. Thrust systems. Am. Assoc. Petrol. Geol. Bull. 66, 1196-1230.

CGS, 1999. Report of the geological survey of the 1999 Chi-Chi earthquake (in Chinese). Central Geological Survey, Taipei.

Chang, S.L., 1971. Subsurface geologic study of the Taichung basin. Petrol. Geol. Taiwan 8, 21-45.

Chang, C.C., Wu, Y.M., Shih, T.C., Wang, C.Y., 2000. Relocation of the 1999 Chi-Chi earthquake in Taiwan. Terres. Atmos. Ocean. Sci. 11, 581-590.

Chen, Y.G., Liu, T.K., 1991. Radiocarbon dates of river terraces along the Lower Tahanchi, northern Taiwan: their tectonic and geomorphic implications. Proc. Geol. Soc. China 34, 337-347.

Chen, W.S., Erh, C.H., Chen, M.M., Yang, C.C., Chang, E.S., Liu, T.K., Horng, C.S., Shea, K.S., Yeh, M.G., Wu, J.C., Ko, C.T., Lin, C.C., Huang, N.W., 2000a. The evolution of foreland basins in the western Taiwan: evidence from the Plio-Pleistocene sequences. Cent. Geol. Surv. Bull. 13, 137-156.in Chinese.

Chen, W.S., Chen, Y.G., Liu, T.K., Huang, N.W., Lin, C.C., Sung, S.H., Lee, K.J., 2000b. Characteristics of the Chi-Chi earthquake ruptures. Spec. Publ. Cent. Geol. Surv. 14, 139-154.in Chinese.

Chen, W.S., Huang, B.S., Chen, Y.G., Lee, Y.H., Yang, C.N., Lo, C.H., Chang, H.C., Sung, Q.C., Huang, N.W., Lin, C.C., Sung, S.H., Lee, K.J., 2001. Chi-Chi earthquake, 1999 September 21: a case study on the role of thrust-ramp structures for generating earthquakes. Bull. Seis. Soc. Am. 5, 986-994.

Chiu, H.T., 1971. Folds in the Northern Half of Western Taiwan. Petrol. Geol. Taiwan 8, 7-19.

Cox, R.T., 1994. Analysis of drainage-basin symmetry as a rapid technique to identify areas of possible Quaternary tilt-block tectonics. An example from the Mississippi Embayment. Geol. Soc. Am. Bull. 106, 571-581.

Gupta, S., 1997. Himalayan drainage patterns and the origin of fluvial megafans in the Ganges foreland basin. Geology 25 (1), 11-14.

Hung, J.H., Suppe, J., 2000. Subsurface geometry of the Chelungpu fault and surface deformation style. Inter. Workshop Ann. Commun. Chi-Chi Earthquake 1, 133-144.

Hung, J.H., Wiltschko, D.V., 1993. Structure and kinematics of arcuate thrust faults in the Miaoli-Cholan area of western Taiwan. Petrol. Geol. Taiwan 28, 59-96. 
Jackson, M., Bilham, R., 1994. Constraints on Himalayan deformation inferred from vertical velocity fields in Nepal and Tibet. J. Geophys. Res. 99, 13897-13912.

Ku, C.C., 1963. Photogeologic study of terraces in northwestern Taiwan. Proc. Geol. Soc. China 6, 51-60.

Liu, T.K., 1990. Neotectonic crustal movement in Northeastern Taiwan inferred by radiocarbon dating of terrace deposits. Proc. Geol. Soc. China 33, 65-84.

LSB, 1999. Vertical and horizontal displacements from GPS measurements in the Chi-Chi earthquake hazard. Land Survey Bureau, Ministry of Interior Taiwan.
Meng, C.Y., 1963. San-I overthrust. Petrol. Geol. Taiwan 2, 1-20.

Shih, R.C., Ho, S.J., Chang, H.C., Lin, C.W., 2000. Preliminary subsurface images of the Chelungpu fault by using shallow seismic reflection. Proc. Inter. Workshop Ann. Commun. Chi-Chi Earthquake $1,123-132$.

Suppe, J., 1981. Mechanics of mountain-building and metamorphism in Taiwan. Mem. Geol. Soc. China 4, 67-89.

Suppe, J., 1986. Reactivated normal faults in the western Taiwan foldthrust belt. Mem. Geol. Soc. China 7, 187-200

Teng, L.S., 1996. Extensional collapse of the northern Taiwan mountain belt. Geology 24 (10), 949-952. 